\title{
Spectrophotometric determination of Uranium through complex formation with roxarsone
}

\author{
Nashat M. M. Abd-Alaty * \\ Nuclear Materials Authority, Fakous, Alsharkeiah, Almansheyah, Aldahshan, Dr Mohamed Alanwar street \\ Above alanwar alkoubra pharmacy Cairo, Egypt
}

\begin{abstract}
A new sensitive, accurate, and non-extractive spectrophotometric method was developed for the rapid determination of Uranium in pure form and Uranium ore using roxarsone. The procedure was based on the complex formation between Uranium (VI) and roxarsone. This showed maximum absorption at $\lambda$ max $395 \mathrm{~nm}$ with a linear relationship in the concentration range from $\left(20-100 \mu \mathrm{g} \mathrm{mL}^{-1}\right)$ with a molar absorptivity $9.57 \times 10^{3}\left(1 \mathrm{~mol}^{-1} \mathrm{~cm}^{-1}\right)$. Inductively Coupled Plasma mass spectroscopy (ICP-MS) was used in the study of the interferences caused by some metallic ions, which were effectively masked by tartaric acid and diethylenetriaminepenta-acetic acid (DTPA). The method holds its accuracy and precision well when applied to the determination of the studied Uranium in its pure form and Uranium ore.
\end{abstract}

Keywords: Roxarsone; Uranium; Spectrophotometry; Uranium Ore.

\section{Introduction}

Uranium is a dangerous radioactive material that is found naturally in soil, water, or in the dust. The estimation of Uranium is essential to decide on the feasibility of extracting it from a specific area and avoiding direct exposure to high doses of radiation or high doses of dust containing Uranium, which causes serious health hazards in the case of swallowing. Therefore, the determination of Uranium in a new, quick and cheap method is important, roxarsone was used in the present study as a reagent of detecting the concentration of uranium ion in a sample of water and rocks.<smiles>CC(=O)O[Cl+3]([O-])([O-])OC(C)=O</smiles>

\section{Urany lacetate}

Uranium ore always contains other metal impurities 5, so the leaching, adsorption, or biosorption of Uranium vary according to the type of the rock ${ }^{6,7}$. Many techniques have been previously developed for the determination of Uranium; these methods include inductively coupled plasma spectrometry (ICP-AES) ${ }^{8}$, inductively
The reaction mechanism is expected to be via complex formation between U (VI) with roxarsone across the $\mathrm{O}$ atom from the arsenic group $\left(\mathrm{H}_{2} \mathrm{AsO}_{3}\right)$, the hydroxyl group atom, and the Nitro group $\left(\mathrm{NO}_{2}\right)$ atom. Roxarsone has not been used to determinate Uranium or any other metal spectrophotometrically before.

Spectrophotometry applies to the estimation of much lower concentrations than titration methods and has the advantage of being easy to carry out ${ }^{1,2}$. It refers to a polymer formed by electrostatic interaction between polyelectrolytes, which are oppositely charged ${ }^{3,4}$.<smiles>O=[N+]([O-])c1cc([As](=O)(O)O)ccc1O</smiles>

Roxarsone

coupled plasma-mass spectrometry (ICP-MS) ${ }^{9,10}$, ion chromatography (I.C.) 11, capillary zone electrophoresis (C.Z.E.) ${ }^{12}$, flow injection analysis (F.I.A.) ${ }^{13}$ and gamma spectrometry ${ }^{14}$. However, these analyses offer restricted accessibility due to the need for a rather valuable apparatus and higher costs. Spectrophotometry is a comparatively easy substitute 
method, which has been applied in the determination of Uranium concentrations ${ }^{15,16}$.

Roxarsone (4-hydroxy-3-nitrophenylarsonic acid) is an aromatic arsenical compound used in the poultry industry, and for the treatment of coccidial intestinal parasites ${ }^{17}$. Biological activities result in the incorporation of arsenic into organic molecules such as arsenobetaine, arsenosugars, and arsenolipids, which are found in many marine organisms ${ }^{18}$.

Uranium was determined spectrophotometrically in other methods using synthesized sulfacetamide azo dye derivative ${ }^{19}$, meloxicam ${ }^{20}, 2$-(2- thiazolylazo)-pcresol (tac) ${ }^{21}$, arsenazo iii ${ }^{22}$, 2-ethanolimino-2pentylidino-4-one ${ }^{23}$, a mixture of - xylene and benzene ${ }^{24}$, azide ions ${ }^{25}$, 2-(5-bromo-2pyridylazo)-5-diethylaminophenol ${ }^{26}, 2-H y d r o x y-1-$ naphthaldehyde-P-hydroxybenzoichydrazone 27 , thiocyanate 28 and 7-iodo-8-hydroxyquinoline-5sulfonic acid (ferron) ${ }^{29}$. Uranium was used in the spectrophotometric determination of piroxicam and tenoxicam ${ }^{30}$, sulfur-containing compounds ${ }^{31}$, phosphorylated proteins ${ }^{32}$, tetracyclines ${ }^{33}$, acylthiosemicarbazide ${ }^{34}$, diiodoquin, clioquinol 35 and serum cholesterol ${ }^{36}$. The spectrophotometric reaction was used in the present study as a method for detecting the concentration of uranium ion in an unknown sample.

\section{Experimental}

\subsection{Instruments}

Metertech Inc. SP-8001 UV-VIS spectrophotometer (Taiwan, R.O.C.) with $1 \mathrm{~cm}$ quartz cells connected to an I.B.M. computer loaded with software application, Icp mass spectroscopy (ICP-MS) Hewlett-Packed 4500 (HP 4500) inductively coupled plasma mass spectrometer (ICP-MS), the system can measure trace elements as low As one part per trillion (ppt) and quickly scan more than 70 elements.

\subsection{Materials and Reagents of the working solution}

Chemicals used for the method were of the highest purity as available from their sources in the form of pure analytical grade:

Uranyl acetate obtained from Fluka/Sigma-Aldrich (St. Louis, MO): $0.5 \mathrm{mgmL}^{-1}$ solution in distilled water.

Roxarsone purchased from Sigma with purity greater than $98 \%$ : prepared as $0.15 \% \mathrm{w} / \mathrm{v}$ by dissolving 0.15 $\mathrm{g}$ of roxarsone in $100 \mathrm{~mL}$ distilled water.

Diethylenetriaminepenta-acetic acid (DTPA) purchased from Aldrich Chemical Company (USA.).: prepared as $0.02 \% \mathrm{w} / \mathrm{v}$ by dissolving $0.02 \mathrm{~g}$ of DTPA in $100 \mathrm{ml}$ deionized water.

Tartaric acid: prepared as $1 \%$. W/v by dissolving $1 \mathrm{~g}$ of tartaric acid (Merck) in $100 \mathrm{ml}$ deionized water.

Phosphate rock from Nile valley Elsebaeiya, Egypt.

\subsection{The procedure of standard Uranium in pure form}

With high accuracy $(0.5-2.5 \mathrm{mg})$ of pure standard uranyl acetate was transferred to a $25 \mathrm{~mL}$ volumetric flasks, $3 \mathrm{~mL}$ of $0.15 \%$ solution of roxarsone was added at room temperature then diluted with $20 \mathrm{~mL}$ distilled water at room temperature. The volumes were completed with distilled water, and the absorbance was measured at $\lambda \max 395 \mathrm{~nm}$ against blank similarly prepared to neglect uranyl acetate, and the results obtained were compared with the reference method ${ }^{37}$ (Table 1).

\subsubsection{Uranium ore method}

This part was done to confirm the validity of the method and the possibility of the application on Uranium ore. The rock used was phosphate rock from Nile valley Elsebaeiya which contain 100 ppm uranium, $650 \mathrm{ppm} \mathrm{Mn} \mathrm{(II),} \mathrm{1700ppm} \mathrm{Ca} \mathrm{(II),}$ 1850ppm Fe (III), 21.3 ppm Ni (II), 13.2 ppm Cu (II), $1250 \mathrm{ppm} \mathrm{Al}$ (III), $132 \mathrm{ppm} \mathrm{Zr(IV)} \mathrm{(analyzed} \mathrm{by} \mathrm{ICP}$ MS).

The rock was crushed with a rock crusher, then the resulting powder was divided into 20 parts, and a portion was taken from each part until it reaches the required weight. The contents of $15 \mathrm{~g}$ finely powdered rock were weighed and mixed well, transfer from powdered rock an accurately weighed quantity equivalent to $1 \mathrm{mg}$ uranyl acetate, $50 \mathrm{~mL}$ of $4 \mathrm{~N} \mathrm{HNO}_{3}$ was added. The mixture was evaporated to near dryness on a hot plate. The addition of $15 \mathrm{~mL}$ followed this concentrated $\mathrm{H}_{2} \mathrm{SO}_{4} 98 \%$. It evaporated to dryness on a hot plate, dissolved in $2 \times 8 \mathrm{ml}$ portions of deionized water. The mixtures were homogenized by shaking for 5 minutes, then filtered into a $25 \mathrm{ml}$ volumetric flask, $2 \mathrm{~mL}$ of DTPA, $1 \mathrm{~mL}$ of tartaric acid, and $3 \mathrm{~mL}$ of roxarsone reagent solution were added. The solution was filled up to the mark with deionized water. The absorbance of the complex was measured at $395 \mathrm{~nm}$ and determined against a reagent blank as the reference prepared simultaneously. The results obtained were compared with the official method ${ }^{37}$, as shown in (Table 2).

\subsection{Interference Study}

\subsubsection{Metals interference}

The effect of different metals on the determination of Uranium with roxarsone was carefully studied, a solution containing other metals was treated as the procedure step by step. The data demonstrate that Uranium could be determined in the presence of other minerals that interfere with Uranium in other spectrophotometric methods. Metal ions $60 \mathrm{mgmL}^{-1}$ concentration like Mn (II), Ca (II), Fe (III), Ni (II), Co (II), $\mathrm{Cu}$ (II) and $\mathrm{Al}$ (III) were found not to interfere significantly up to concentration $\quad 150 \mathrm{mgml}^{-1}$ with Average of three experiments

(Recovery\%) 99.6, 99, 98.7, 100.3, 99.4, 99.8, 99 and 98.8 respectively. The presence of $\mathrm{Zr}$ (IV), Mo (VI) and $\mathrm{Pb}$ (II) up to $120 \mathrm{mgmL}^{-1}$ was successfully masked by DTPA and tartaric acid with recovery\% 
99.1,98.7 and 98.6, respectively. This step was detected by Inductively coupled mass spectroscopy (ICP-MS) to confirm the validity of the study. The data obtained gave the same results as those of roxarsone spectrophotometry with a good recovery percentage.

\subsubsection{Clay, silt and sand interference}

Each of these rock contents examined alone after will grinding and powdering then take $10 \mu \mathrm{g}$ mixed with $60 \mu \mathrm{g} \mathrm{mL}^{-1}$ uranium complexed with roxarsone and repeated tree times to inshore the statistical recovery $\%$.

\section{Results and Discussion}

The previous procedures were applied to

a- Different concentrations of pure Uranium, the results obtained, and compared with the reference method ${ }^{37}$ and shown in (Table1).

b- Uranium ore and the results compared with the reference method ${ }^{37}$ are shown in (Table 2).

c- $60 \mu \mathrm{g} \mathrm{ml}^{-1}$ of Uranium in the presence of clay, slit, and finely powdered sand, the results obtained are shown in (Table 3).

Statistical analysis of the results indicates that the proposed method was precise and accurate (Table 4).

Table 1. Determination of pure Uranium using roxarsone at $\lambda \max 395 \mathrm{~nm}$.

\begin{tabular}{|c|c|c|}
\hline \multicolumn{3}{|l|}{ Uranium } \\
\hline Taken $\left(\mu \mathrm{g} \mathrm{mL} L^{-1}\right)$ & Found $\left(\mu \mathrm{g} \mathrm{mL}^{-1}\right)$ & Recovery ${ }^{b} \%$ \\
\hline $\begin{array}{l}20 \\
40 \\
60 \\
80 \\
100\end{array}$ & $\begin{array}{l}20.09 \\
39.36 \\
59.67 \\
79.12 \\
100.2\end{array}$ & $\begin{array}{l}100.45 \\
98.40 \\
99.45 \\
98.90 \\
100.2\end{array}$ \\
\hline $\begin{array}{l}\text { Mean recovery } \\
\text { N } \\
\text { Variance } \\
\text { S.E } \\
\text { Molar absorptivity } \\
\text { Sandell's sensitivity } \\
\text { t-test } \\
\text { F-test }\end{array}$ & $\begin{array}{c}99.48 \pm 0.860 \\
5 \\
0.740 \\
0.384 \\
9.57 \times 10^{3}\left(1 \mathrm{~mol}^{-1} \mathrm{~cm}^{-1}\right) \\
2.4 \times 10^{-2}\left(\mu \mathrm{g} \mathrm{cm}^{-2}\right) \\
0.3 \\
1.09\end{array}$ & \\
\hline
\end{tabular}
(a)Mean \pm S.D.
(b)Average of three experiments

Table 2. Determination of Uranium in $100 \mathrm{ppm}$ uranium ore by complexation with roxarsone using standard addition technique.

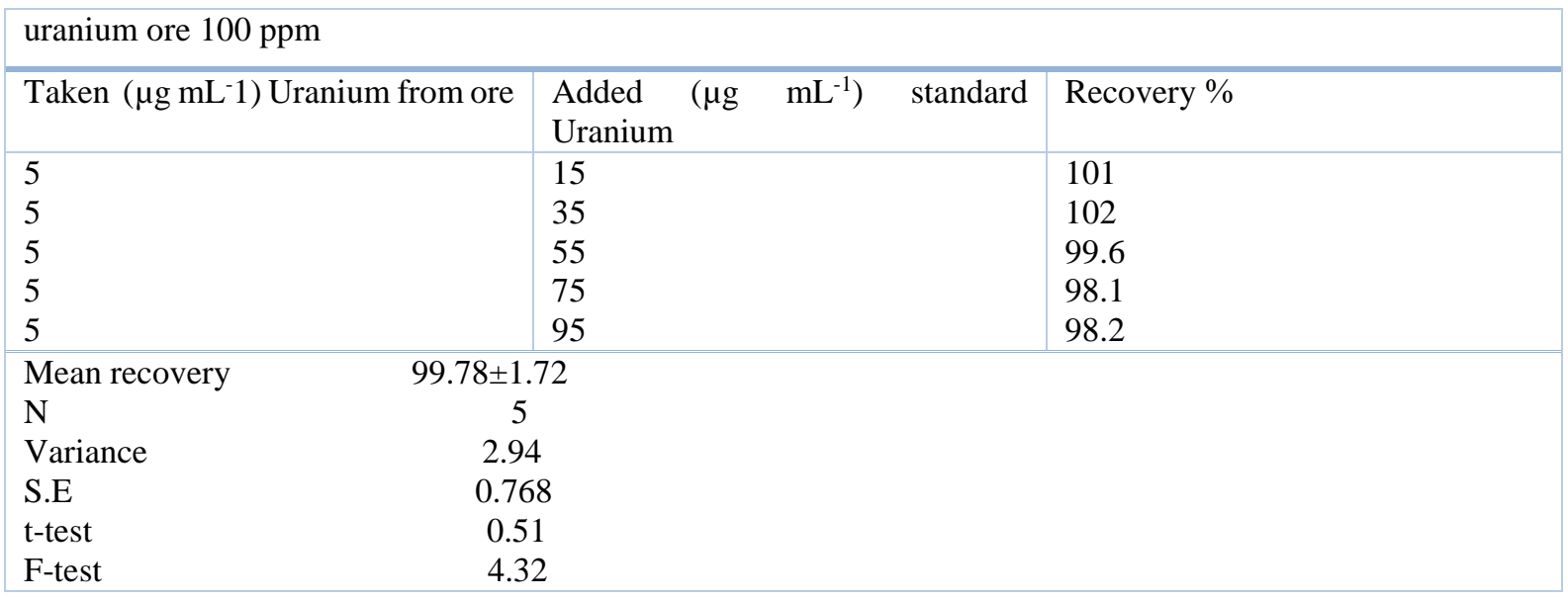
(a)Mean \pm S.D.
(b)Average of three experiments. 
Table 3. Effect of some common ingredients on the determination of Uranium using roxarsone.

\begin{tabular}{|c|c|c|}
\hline \multirow[b]{2}{*}{$\begin{array}{l}\text { Other } \\
\text { Ingredients } \\
10 \mu \mathrm{g} . \text { added }\end{array}$} & \multicolumn{2}{|l|}{ Uranium } \\
\hline & Taken $\left(\mu g \mathrm{~mL}^{-1}\right)$ & Recovery \% \\
\hline $\begin{array}{l}- \\
\text { clay } \\
\text { slit } \\
\text { sand } \\
\text { carbonate }\end{array}$ & $\begin{array}{l}60 \\
60 \\
60 \\
60 \\
60\end{array}$ & $\begin{array}{l}99.6 \\
99 \\
98.7 \\
100.3 \\
99.8\end{array}$ \\
\hline
\end{tabular}

(a) Average of three experiments

Table 4. Evaluation of the accuracy and precision of the proposed methods.

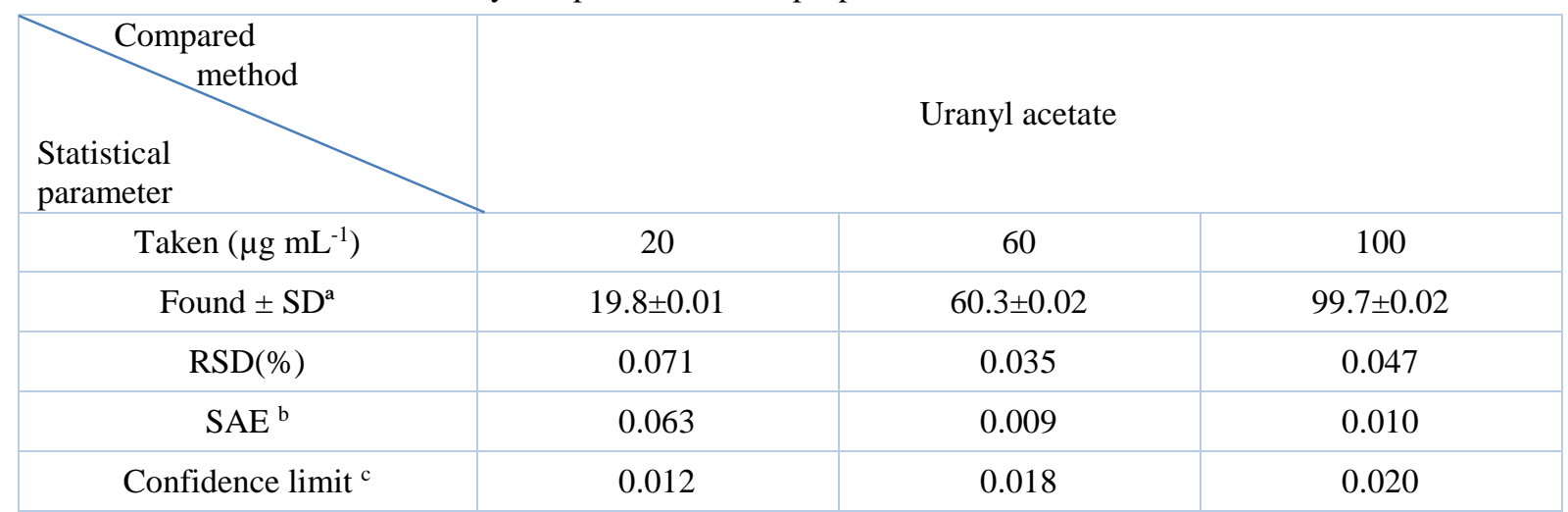

${ }^{a}$ Mean \pm standard deviation for five determinations.

b Standard analytical error.

${ }^{\mathrm{c}}$ Confidence limits at $\mathrm{P}=0.95$ and 4 degrees of freedom.

These results and precise statistical data were due to a new complex formation with a dark yellow color; it was obtained due to the interaction of uranyl ion with the oxygen in $-\mathrm{O} . \mathrm{H}$. and $\mathrm{NO}_{2}$ functional groups. The complex achieved may be due to the interaction of uranyl ion with roxarsone as explained following mechanism (Scheme 1).

\section{Step 1}

$$
\mathrm{UO}_{2}(\mathrm{AC})_{2} 6 \mathrm{H}_{2} \mathrm{O} \longrightarrow \mathrm{UO}_{2}{ }^{2+}+2 \mathrm{AC}^{-}+6 \mathrm{H}_{2} \mathrm{O}
$$

\section{Step 2}<smiles>O=[N+]([O-])c1cc([As](=O)(O)O[Al]2Oc3ccc([As](=O)(O)O)cc3N3N2c2cc([As](=O)(O)O)ccc2O[Al]3O)ccc1O</smiles>

Scheme 1. A suggested complex obtained may be due to the interaction between uranyl ion with roxarsone

The reaction product is suitable for spectrophotometric measurement in this study, the studied uranium exhibit colored condensation product with roxarsone that was measured at 
$\lambda \max 395 \mathrm{~nm}$ but uranyl acetate alone was measured at $265 \mathrm{~nm}$ while roxarsone $\lambda \max$ was at $244 \mathrm{~nm}$, this

indicates the formation of the complex (Fig. 1).

\subsection{Effect of solvent}

In this work, distilled water, ethanol, chloroform, toluene, methanol, benzene, and methylene chloride were studied. Distilled water represents the optimum diluting solvent with maximum absorbance.

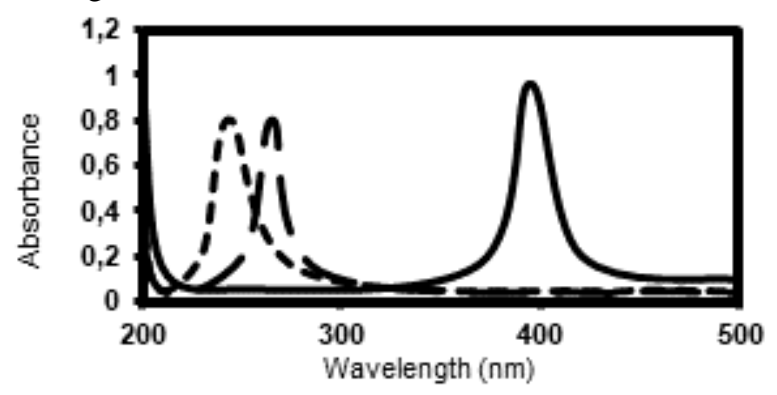

Figure 1. Absorption spectra of $100 \mu \mathrm{g} \mathrm{ml}^{-1}$ of Roxarsone $0.15 \%$ at -uranyl acetate at $\lambda \max 265 \mathrm{~nm}$, Reaction product of $100 \mu \mathrm{g} \mathrm{ml}^{-1}-\lambda \max 244 \mathrm{~nm}$ and of uranyl acetate in distilled water with $0.15 \%$ roxarsone at $\lambda \max$.

\subsection{Reaction kinetics}

The reaction was carried out at $25 \pm 1{ }^{\circ} \mathrm{C}$, and the complex formed with maximum absorption quickly in 1 to 1.5 minutes and was stable for more than 20 hours (Fig. 3).

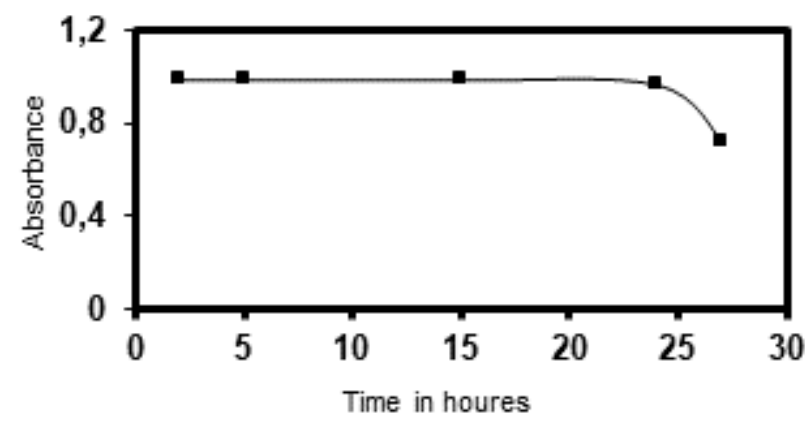

Figure 3. Effect of time on the color intensity of the reaction product between $3 \mathrm{ml}$ $0.15 \%$ roxarsone and $100 \mu \mathrm{g} \mathrm{ml}^{-1}$ of uranyl acetate.

\subsection{Effect of $\mathbf{p H}$}

$\mathrm{pH}$ was carefully examined by preparing buffered solutions of $\mathrm{pH}$ from 1 to $10^{38}$, Influence of $\mathrm{pH}$ on uranyl acetate solutions at different $\mathrm{pH}$ values (1-10) were assayed to determine the variation of concentrations with $\mathrm{pH}$ on this protocol. The concentrations determined using this modified method was not affected significantly with the variation in the $\mathrm{pH}$ from 2 to 8 . (Fig. 5) shows the

\subsection{Effect of heating temperatures}

Different temperatures varying from ambient to $70^{\circ} \mathrm{C}$ were studied. It was found that heating did not enhance the complexation reaction; at $50^{\circ} \mathrm{C}$ the absorbance starts decreasing, and the complex begins to disintegrate (Fig. 2).

The optimal reaction conditions were carefully studied, as mentioned in the following paragraphs:

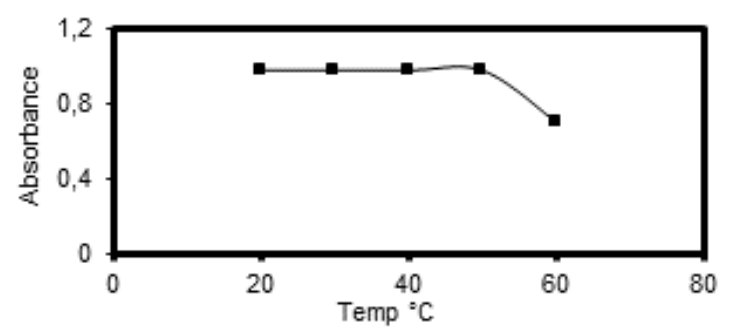

Figure 2. Effect of temperature on the color intensity of the reaction product between $3 \mathrm{ml}$ $0.15 \%$ roxarsone and $100 \mu \mathrm{g} \mathrm{ml}^{-1}$ of Uranyl acetate.

\subsection{Effect of reagent volumes}

It was found that the sufficient volume was three Ml of $0.15 \%$ roxarsone to achieve maximum color intensity (Fig. 4).

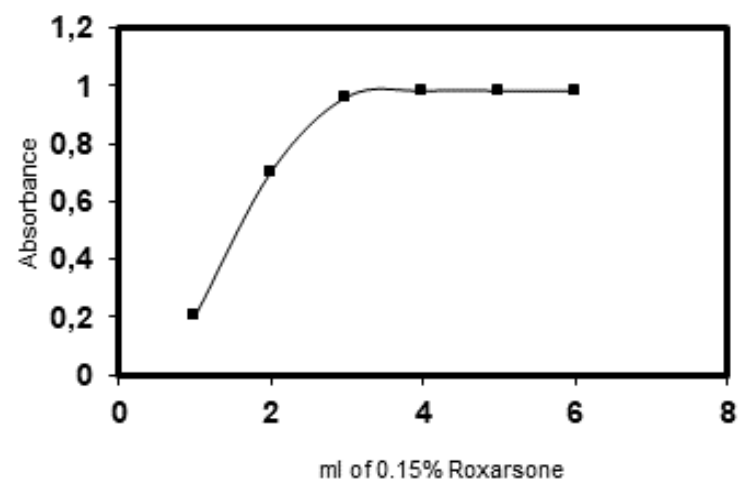

Figure 4. Effect of volume of $0.15 \%$ roxarsone on the colour intensity of the reaction product with $100 \mu \mathrm{g} \mathrm{ml}^{-1}$ uranyl acetate.

change of the color intensity of the reaction as a function of $\mathrm{pH}$ values.

\subsection{Stoichiometry}

Effect of the order of addition on studying the molar ratio of the studied uranyl acetate by the continuous variation method (Job's method) ${ }^{39}$ of equimolar solutions in the presence of an excess amount of roxarsone; it was found to be 1: 1 of uranyl ion and roxarsone (Fig. 6). 


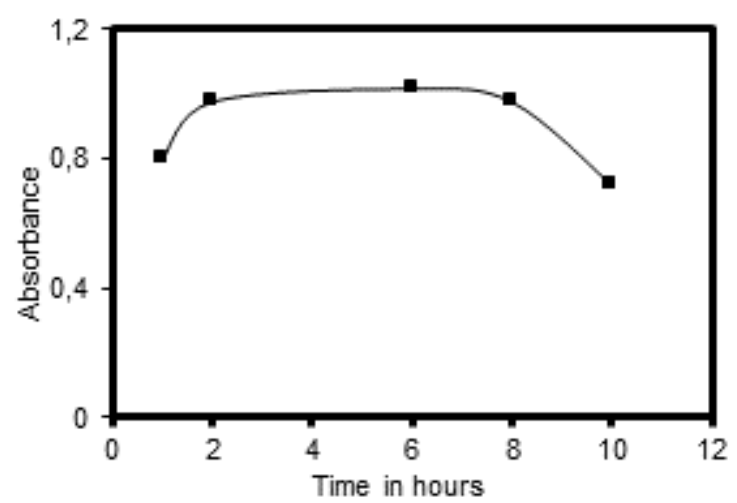

Figure 5. Effect of $\mathrm{pH}$ on the color intensity of the reaction product between $3 \mathrm{ml} 0.15 \%$ roxarsone and $100 \mu \mathrm{g} \mathrm{ml}^{-1}$ of uranyl acetate.

\subsection{Linearity and quantification}

A linear relationship was obtained for the absorbance

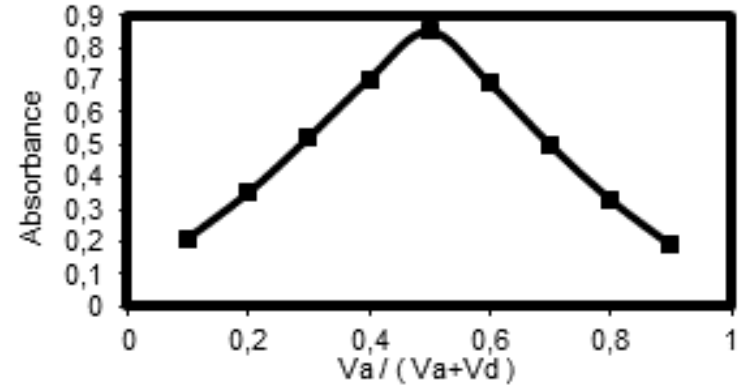

Figure 6. Continous variation plot for $\left(1.5 \times 10^{-3} \mathrm{M}\right)$ uranyl acetate and $\left(1.5 \times 10^{-3} \mathrm{M}\right)$ of roxarsone $\mathrm{Va}=$ volum of uranyl acetate and $\mathrm{Vd}=$ volum of roxarsone.

of uranyl acetate with roxarsone in the concentration ranges of 20-100 $\mathrm{g} \mathrm{mL}^{-1}$ (Fig. 7).

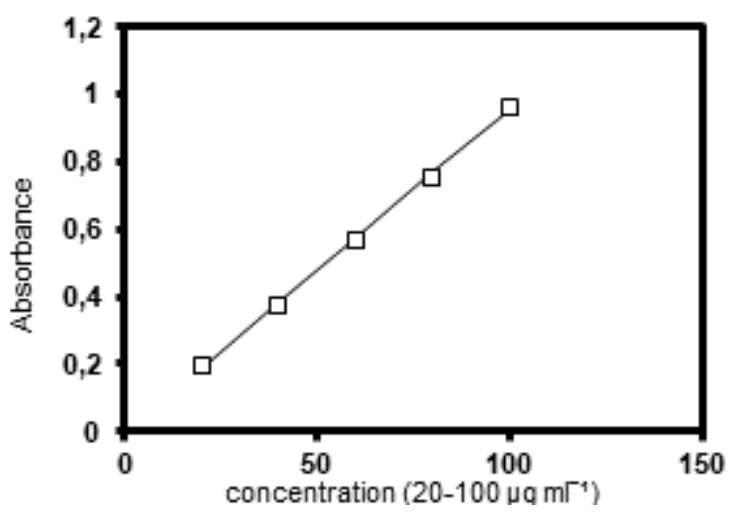

Figure 7. Calibration curve of the reaction product of Uranyl acetate with roxarsone at $\lambda \max 395 \mathrm{~nm}$.

The following equations describe the calibration graphs :

at $\lambda \max 395 \mathrm{~nm}$

$\mathrm{A}=0.00957 \mathrm{C}$

Where $\mathrm{A}$ is the absorbance and $\mathrm{C}$ is the concentration of uranyl acetate in the final solution in $\mu \mathrm{g} \mathrm{mL}^{-1}$.

\section{Conclusion}

The proposed method was successfully applied for the determination of Uranium, and the validity of the process was assessed by comparing the calculated $t$ and $F$ values with the reference method, the results showed no significant difference between them. DTPA and tartaric acid successfully masked the presence of $\mathrm{Zr}$ (IV), Mo (VI) and $\mathrm{Pb}$ (II) up to 120 mgmL-1. Clay, silt, sand, and carbonate do not interfere with the new complex formation. No extraction step is required and therefore the employment of organic solvents, which are commonly toxic pollutants, is avoided. Uranium ore was analyzed by the proposed method applying the standard addition technique and compared with the reference method. Statistical analysis of the results revealed that the proposed method was highly precise and accurate as of the reference one.

\section{Acknowledgment}

The corresponding author acknowledges Nuclear Materials Authority for facilitating the research work.

\section{References}

1- P. Subrahmanyam, B. Krishnapriya, K. Suvardhan, D. Rekha, Y. Suneeta, B. Jayaraj, P. Chiranjeevi, Simple, selective, and sensitive spectrophotometric determination of fenitrothion using a novel chromogenic reagent, Journal of Hazardous Materials, 2007, 146, 51-57.

2- H. G. Daabees, A new sensitive spectrophotometry method for the analysis of some antihistamines, Spectroscopy Letters, 1999, 32, 913-930.

3- T. T. D. Tien, P. N. D. Uyen, T. B. T. Huong, T. N. Trang, Effect of electrostatic interaction between fluoxetine and lipid membranes on the partitioning of fluoxetine investigated using second derivative spectrophotometry and FTIR, Chemistry and Physics of Lipids, 2017, 207, 10-23. 
4- W. Wei, W. Min, K. Xuejun, W. Ping, L. Songqin, Spectrophotometry study of the interaction of hyaluronic acid with methylene blue and its analytic application, Analytical Letters, 2008, 41, 599-607.

5- H. A. El Nahas, M. G. El Feky, H. I. Mira, Mineralogy, m-type tetrad effect, and radioactivity of altered granites at the $\mathrm{g}$. abu garadi shear zone, central-eastern desert, Egypt, Chinese Jor. of Geochem., 2011, 30, 153-164.

6- M. F. Cheira, H. I. Mira, A. K. Sakr, S. A. Mohamed, Adsorption behaviors of Uranium (vi) from the acid solution using treated waste clay, Nucl. Sci. and Techniques, 2019, 30, 156-174.

7- A. H. Abd El Hameed, W. E. Eweda, K. A. Abou-Taleb, H. I. Mira, Biosorption of Uranium, and heavy metals using some local fungi isolated from phosphatic fertilizers, Annal of Agricultural Sci., 2015, 60, 345-351.

8- O. Fujino, S. Umetani, E. Ueno, K. Shigetaa, T. Matsuda, Determination of Uranium and thorium in apatite minerals by inductively coupled plasma atomic emission spectrometry with solvent extraction separation into diisobutyl ketone, Anal. Chim. Acta, 2000, 420, 65-71.

9- J. G. Gupta, N. B. Bertrand, Direct ICP-MS determination of trace and ultra-trace elements in geological materials after decomposition in a microwave oven. I. Quantitation of Y, Th, U, and the lanthanides, Talanta, 1995, 42, 1595-1607.

10-S. Joannon, P. Telouk, C. Pin, Determination of $\mathrm{U}$ and $\mathrm{Th}$ at ultra-trace levels by isotope dilution inductively coupled plasma mass spectrometry using a geyser-type ultrasonic nebulizer: application to geological samples, Spectrochim. Acta B, 1997, 52, 1783-1789.

11-E. H. Borai, A. S. Mady, Separation, and quantification of ${ }^{238} \mathrm{U},{ }^{232} \mathrm{Th}$ and rare earth in monazite samples by ion chromatography coupled with on-line flow scintillation detector, Appl. Radiat. Isot, 2002, 57, 463-469.

12-B. Liu, L. Liu, J. Cheng, Separation and determination of thorium, Uranium, and mixed rare-earth elements as their U.V./Vis absorbing complexes by capillary zone electrophoresis, Talanta, 1998, 47, 291-299.

13-Y. Hirano, Y. Ogawa, K. Oguma, Simultaneous spectrophotometric determination of Uranium and thorium by flow injection analysis using selective masking Anal. Sci., 2003, 19, 303-307.

14-N. Dufoura, J. Dumazert, E. Barat, G. H. V. Bertrand, F. Carrel, T. Dautremer, F. Lainea, A. Sari, Measurement of low-activity uranium contamination by gamma-ray spectrometry for nuclear decommissioning, Nuclear Instruments and Methods in Physics Research Section A: Accelerators, Spectrometers, Detectors, and Associated Equipment, 2020, 951, 162976.

15-Z. Marczenko, Separation and Spectrophotometric Determination of Element, Chichester: E. Horwood; New York: Halsted Press, 1986.
16-H. Onishi, Photometric Determination of Traces of Metals Fourth Edition Part I.I.B.: Individual Metals, Magnesium to Zirconium, A WileyInterscience Publication, New York, 1989, 411-418.

17-H. D. Chapman, Z. B. Johnson, use of antibiotics and roxarsone in broiler chickens in the USA: analysis for the years 1995 to 2000, Poultry Science, 2002, 81, 356-364.

18-J. Edmonds, K. Francesconi, Transformations of arsenic in the marine environment, Experientia, 1987, 43, 553-557.

19-K. Elgendy, A. El-didamony, B. Abd El-wahaab, Analytical applications using the spectrophotometric technique for the determination of Uranium (VI), samarium(III) and cerium(III) by a new organic reagent, Journal of the Iranian Chemical Society, 2020, 1-11.

20-K. Lutfullah, N. A. Mohd, R. Nafisur, N. H. A. Syed, Optimized and validated spectrophotometric method for the determination of Uranium (VI) via complexation with meloxicam, Journal of Hazardous Materials. 2008, 155, 261-268.

21-S. G. Leonardo, C. S. C. Antonio, L. C. F. Sergio, L. F. Maria, S. C. Marcelo, Spectrophotometric determination of Uranium using 2-(2-thiazolylazo)-p-cresol (tac) in the presence of surfactants, J. Braz. Chem. Soc., 1999, 10, 519-522.

22-N. Ali, G. Nahid, G. Mohammad, E. Ali, Simultaneous Spectrophotometric Determination of Uranium and Thorium Using Arsenazo III by H-Point Standard Addition Method and Partial Least Squares Regression, Journal of the Chinese Chemical Society, 2007, 54, 411-418.

23-S. O. Adel, E. Adel, A. S. Medhat, E. A. Alaa, Bulletin of the Chemists and Technologists of Macedonia. 2007, 24, 11-19.

24-N. S. B. Singh, S. V. Mohan, A spectrophotometric method for uranium determination, Journal of Radioanalytical and Nuclear Chemistry, 1979, 52, 319-327.

25-D. R. Do Carmo, J. F. de Andrade, O. M. Guimares, Spectrophotometric determination of Uranium through uranyl, azide system, Analytical Letters, 1995, 28, 1897-1911.

26-K. Danchana, C. T. de Souza, E. Palacio, V. Cerda, Multisyringe flow injection analysis for the spectrophotometric determination of Uranium (VI) with 2-(5-bromo-2-pyridylazo)-5diethylaminophenol, Microchemical Journal, 2019, 150, 104148 .

27-V. S. A. Devi, V. K. Reddy, 2-Hydroxy-1naphthaldehyde-p-hydroxybenzoichydrazone: a new chromogenic reagent for the determination of thorium (iv) and Uranium (vi), Journal of Chemistry, 2013, 697379.

28-C. E. Crouthamel, C. E. Johnson, Spectrophotometric determination of Uranium by thiocyanate method in acetone medium, Anal. Chem., 1952, 24, 1780-1783. 
29-R. Ali, A. Suhail, M. Ejaz, Spectrophotometric determination of Uranium (VI) with 7-iodo-8hydroxyquinol ine-5-sulfonic acid (ferron), Journal of Radioanalytical and Nuclear Chemistry, 1979, 49, 205.

30-M. A. El-Ries, Spectrophotometric determination of piroxicam and tenoxicam in pharmaceutical preparations using uranyl acetate as a chromogenic agent, Analytical Letters, 1998, 31, 793-807.

31-A. T. Elham, Y. H. Nagiba, A. A. Fahima, E. A. Laila, Fluorimetric Determination of Some Sulfur-Containing Compounds Through Complex Formation with Terbium $\left(\mathrm{Tb}^{+3}\right)$ and Uranium $\left(\mathrm{U}^{+3}\right)$, Journal of Fluorescence, 2007, 17, 293-300.

32-H. K. Line, E. N. Peter, I. J. Christian, B. K. Birthe, E. M. Niels, Phosphate Selective Uranyl Photo-Affinity Cleavage of Proteins.
35-U. Saha, A. K. Sen, T. K. Das, Spectrophotometric determination of clioquinol and diodoquin in pharmaceutical preparations using uranyl acetate as a chromogenic agent, Analyst, 1988, 113, 1653-1655.

36-A. C. Parekh, D. H. Jung, Cholesterol determination with ferric acetate-uranium acetate and sulfuric acid-ferrous sulfate reagents, Anal. Chem., 1970, 42, 1423-1427.

37-Y. Hirano, Y. Ogawa, K. Oguma, Simultaneous Spectrophotometric Determination of Uranium and thorium by flow injection analysis using selective masking, Analytical Sciences, 2003, 19, 303-307.

38-M. H. Gabb, W. E. Latchem, A Handbook of Laboratory Solutions, NewYork, Chemical Publishing Company Inc., 1968.

39-J. Rose, Advanced physicochemical experiments, Pitman, London, England, 1964, 54.

Determination of Phosphorylation Sites,

ChemBioChem J., 2008, 9, 2377-2381.

33-U. Saha, A. K. Sen, T. K. Das, S. K. Bhowal, Spectrophotometric determination of tetracyclines in pharmaceutical preparations, with uranyl acetate, Talanta, 1990, 37, 1193-1196.

34-V. A. Madalina, L. A. Gabriela, T. Rosua, M. Negoiu, A. Eva-Ruxandra, R. Jenny, Copper(II), and uranyl(II) complexes with acylthiosemicarbazide: Synthesis, characterization, antibacterial activity and effects on the growth of promyelocytic leukemia cells HL-60, European Journal of Medicinal Chemistry, 2009, 44, 3323-3329. 